e-makâlât Mezhep Araştırmaları, VII/2 (Güz 2014), ss. 71-102.

ISSN 1309-5803 | www.emakalat.com

\title{
HAYDERİZADE İBRAHİM EFENDİ'NİN VEHHÂBÎLİK ADLI MAKALESI
}

Osman ORAL*

\begin{abstract}
Öz
Yaklaşık iki asır önce Arap Yarımadası'nda Muhammed b. Abdilvehhab (v.1206/1792) tarafindan kurulan Vehhabilik, bugün Suudi Arabistan'in resmi mezhebi durumundadir. Vahhabilik, Osmanlılarda davranışlarındaki sertlik, imanlarındaki taassup ve kendi inanışlarında olmayanları küfürle suçlamak bakımlarından "Haricilik" hareketi olarak bakılmıştır. Osmanlı'nın 36. Padişah1 VI. Mehmed Vahideddin (1918-1922) zamanının 170. Şeyhülislamı Hayderizâde İbrahim Efendi (v.1349/1933) de Vahhabi mezhebinin kurulması, gelişmesi, fikirleri ve yayılması ile ilgili "Sebilürreşâd" Dergisi'nde dört makale kaleme almıştır. Kendisi Medresetü'l-Vaizin'de "Mezahib ve Turuk-u İslâmiye Tarihi" dersi veren eserleri olan ihtisas sahibidir. O'nun Sebilürreşâd'da yayınlanan "Vehhâbilik" adlı makalelerini Kelâm ve Mezhepler Tarihi İlmi çerçevesinde sadeleştirmek istiyoruz.
\end{abstract}

Anahtar kelimeler: Vehhabilik, Muhammed b. Abdulvehhab, Mezhep, Tevhid, Bid'at.

\section{Abstract \\ Article of Haydarizade Named Wahhabism}

Nearly two centuries ago, in the Arabian Peninsula Muhammad b. Abdilvehhab (v.1206 / 1792) established by Wahhabi, the official sect of Saudi Arabia today is the case. Wahhabism, in the Ottoman Empire rigidity in behavior, bigotry, and their belief in faith to blame the non-maintenance of disbelief "Kharijism" movement were analyzed. Sultan of the Ottoman Empire 36 VI. Mehmed Vahideddin (1918-1922) time 170 Shaykh al my Hayderizâ İbrahim Efendi (v.1349 / 1933) the Wahhabi sect establishment, development, ideas, and spread about the "Sebilurreşad" in the Journal of four articles pen has written. Medresetü'l-Vaizin in itself "Mezahib and type-Islamic History", which is a specialist who teaches works. Satate published in the "Wahhabi" Kalam's articles and think heresiographical simplification within the framework of Science.

Keywords: Wahhabi, Muhammad b. Abdulvehhab, Sects, Unity, Innovation.

*Yrd. Doç. Dr. Bozok Üniversitesi İlahiyat Fakültesi, Kelam Anabilim Dalı 


\section{GİRIŞ̧}

Mâli durumu iyi ve imkânı olan Müslümanların ömründe bir defa farz olan hac ibadeti vesiyesiyle her y1l binlerce kissinin ziyaret ettiği o kutsal yerdekilerin fikirleri, inanışları, yaptıkları ameller yıllarca halk arasında konuşulmuş, onların görüşleri, mezhebi merak konusu olmuş, orada yaşayanların görüşlerinin bilinmesi de zaruret halini almıştır. Yaklaşık iki asır önce Arap Yarımadasında Muhammed b. Abdilvehhab (v.1206/1792) tarafindan kurulan Vehhabilik, bugün Suudi Arabistan'in resmi mezhebi durumundadır. Muhammed b. Abdilvehhab (v.1206/1792), İbn Teymiyye (v.728/1328)'in eserlerini okumuş, onları beğenmiş, derince incelemiş ve teoriden pratiğe çıkarmış ama ondan daha katı bir tutum izlemiştir. Vahhabilik mezhebi, Türk Düşünce Tarihi'nde davranışlarındaki sertlik, imanlarındaki taassup ve kendi inanışlarında olmayanları küfürle suçlamak bakımlarından "Haricilik" hareketi olarak bakılan bir mezheptir. İslâma girmiş toplulukların imânını korumak, İslâma girmemiş insanların da şüphelerini gidererek İslâma girmeleri sağlamak gâye ve amaciyla faaliyet gösteren İslâmî ilimlerin başında Akâid ve Kelâm İlmi gelir. Mezhep, dini yaşama yolu, metodu, düşünme ve fikir üretme sistemi demektir. İslâm Mezhepleri Tarihi de her mezhebin, firkanın tarih boyunca İslâm dininini nasıl anladığını ortaya koymakta, İslâmın eski ve yeni anlaşılma durumlarını karşılaştırma imkanını vermektedir.

36.Osmanlı Padişahı VI. Mehmed Vahideddin (1918-1922) zamanının 170.Osmanlı Şeyhülislamı Hayderizâde İbrahim Efendi (v.1349/1933) Vahhabi mezhebinin kurulması, gelişmesi, fikirleri ve yayılması ile ilgili Sebilürreşâd Dergisi'nde dört adet makale kaleme almıştır. Bunları günümüze aktarmanın faydalı olabilme ümidindeyiz.

\section{Hayderizâde İbrahim Efendi'nin Hayatı}

Bağdat'in ulemâ yetiştirmiş bir âilesinden Haydarizâde Âsım Efendi'nin oğludur. 1280/1863 yılında Musul yakınındaki Erbil şehrinde doğdu. Orada ilk eğitimini tamamladı. Özel öğretmenlerden sarf, nahiv, mantık, akâid, kelam, tefsir, hadis gibi dersleri al- 
d1. ${ }^{1}$ Adliye Nezâreti/Adalet Bakanlığı'nca açılan sınavda pekiyi derecesinde 1311/1893'de hâkimlik yapma yetkisini ald1. 17 Eylül 1887'de Zalu, 29 Ocak 1890'da Meclisi Maarif Nâzırlığında görevler yapt1. 1320/1902 y1lında Haremeyni Muhteremeyn Pâyesi ile taltif edildi ve üçüncü rütbeden Mecidi nişarı verildi. 08 Ağustos 1904'de Darü'l-Hayri Âli Mektebi Müdürlüğüne atand1. 23 Ağustos 1908'de Diyarbakır Merkez Kadılığılı̆̆ı'na atandı. İki yıl sonra 27 Haziran 1910 tarihinde Defteri Hakani Şer’i memurluğuna getirildi. 17 Eylül 1327/1911 tarihinde Kadastro Mektebi Hukuk kısmı Mecelle Öğretmenliğine tayin olundu. 01 Ekim 1916'da Padişahın emri ile Darü'l-Hikmeti'l-İslâmiyye üyeliğine atandı. 10 Teşrini evvel 1332/1916 yılında Turuk ve Mezâhibi İslâmiyye Dersi Öğretmenliğine tayin olundu. ${ }^{2}$ İbrâhim Efendi, 5 Ağustos 1918 tarihli irâde-i seniyye ile Dârü'l-hikmeti'l-İslâmiyye üyeliğine yeniden tayin edildi. Kısa bir müddet sonra Ahmed İzzet Paşa'nın istifası ile Tevfik Paşa tarafından, Mütareke'nin ve İtilâf devletleri donanmalarının İstanbul önlerine doğru ilerlediği sıkıntılı günlerde kurulan ve İttihatç1lar'a karşı olduğu gibi bir Hürriyet ve İtilâf hükümeti de sayılmayan ve daha ziyade "Padişah kabinesi" diye nitelendirilen kabineye şeyhülislâm olarak tayin edildi (11 Kasım 1918). 12 Ocak 1919'da Ahmed Tevfik Paşa Hükümeti'nin istifası üzerine 2 ay 1 gün süren birinci meşihatı sona erdi. Tevfik Paşa'nın 3.sadaretinde (13 Ocak 1919) tekrar şeyhülislâm olmuştur. Bu görevinden 3 Mart 1919 tarihinde istifa etmiş, Ali Rıza Paşa Hükümeti sırasında 2 Ekim 1919'da üçüncü defa Şeyhülislâm olmuştur. İbrahim Efendi'nin 3.meşihat1, kabinenin 3 Mart 1338/1920'de istifasiyla son buldu. Salih Hulusi Paşa'nın 8 Mart 1338/1920 tarihinde kurduğu kabi-

1 Türk Ansiklopedisi, MEB Ankara 1971, 19/505; Y1lmaz Öztuna, Devletler ve Hanedanlar, Kültür Bakanlığı Yay, Başbakanlık Basımı, Ankara 1989, II, 978

2 Bkz. Sadık Albayrak, Son Devir Osmanlı Ulemâsı, Medrese Yay, İstanbul 1980, II, 169; İsmail Hami Danişmend, Osmanlı Devlet Erkânı, Türkiye Yay, İstanbul 1971, s.163-4; Abdulkadir Altınsu, Osmanlı Şeyhülislâmlar, Ayyıldız Matbaas1, Ankara 1972, s.252. 
neye İbrahim Efendi, 4.kez Şeyhülislâm olarak katıld1. Hükümetin 2 Nisan 1920'de istifasıyla Şeyhülislâmlığı sona erdi. ${ }^{3}$

Dört meşihat süresi toplam 9 ay 20 günü bulmaktadır. Osmanlı Devrinin 126. Şeyhülislâmıdır. Son görevinde bulunduğu sıralarda İstanbul işgal kuvvetleri tarafından işgal edilmişti. Kuvayı Milliye'nin dağıtılması esasına dayanan bir beyannamenin yayınlanması işgal kuvvetlerince istendiğinden hükümetle birlikte Şeyhülislam Hayderizâde İbrahim Efendi de istifa etmiştir. Kazasker olmaksızın Şeyhülislâm olan İbrahim Efendi, saltanatın kaldırılmından sonra 1923 yılında Bağdat'a göçtü. Oğlu Davud Paşa (v.1381/1965) Irak’ta Milli Eğitim Bakanlığı yapmıştır. Hayderizâde İbrahim Efendi, Bağdat'da 1349/1933 yılında vefat etmiş ve oraya defnedilmiştir. Şeyhülislâm Hayderizade İbrahim Efendi'nin Türkiye'den ayrıldıktan sonra ne gibi görevlerde bulunduğu Irak Kültür Ataşeliğinden sorulmuş, 26.12.1970 tarihli cevaplarında, tahminen Vakıflar Divan Başkanlığı'nda bulunduğu bildirilmiş, vakıflarda herhangi bir görev almadığı, Vakıflar Divan Başkanlığı'nın yazısına atfen duyrulmuştur. ${ }^{4}$

\section{Fikirleri}

36. Osmanlı Padişahı VI. Mehmed Vahideddin'in ve Osmanlı devrinin 126. Şeyhülislâmı Hayderizâde İbrahim Efendi, ileri görüşlü bir kişiydi. Bir gün Sultan Vahdettin, kendisine halkın durumunu sorunca: "Vahdet-i vucud gibi vahdet-i cunûd olmuş, buradaki askerle Anadolu'daki asker birleşmişler, eski sadrazamlar padişah uğruna kendilerini feda ederlerdi. Efendimiz sadrazam uğruna nefsi şahanenizi feda ediyorusunuz..." cevabinı vererek, Sultan Vahdeddin'in Damad Ferit Paşa'ya olan tutkunluğunu iğneleyerek belirtmiştir.

3 Bkz. İbnü'l-Emin Mahmut Kemal İnal, Son Sadrazamlar, İstanbul 1969, s.1721; Öztuna, Devlet ve Hanedanlar, s.978; Danişmend, Osmanlı Devlet Erkânı, s. 163; Albayrak, Son Devir Osmanlı Ulemâsı, II, 169.

${ }^{4}$ Bkz. Altınsu, Osmanlı Şeyhülislâmlar, s.253; Öztuna, Devlet ve Hanedanlar. s.978.

5 İnal, Son Sadrazamlar, s.2071-2; Şöyle bir şiir de zikretmektedir: "Hayderizâde hakikat söylemiş. Vâkıf-1 ahvâl olan takdir eder. Gelse insafa eğer Sultan Vahid, Nefsini kendi bile ta'zir eder." 
Damad Ferid Paşa hükümetlerinin Anadolu'daki milliyetçi harekâta karşı olan icraatını özellikle padişahın şahsının sakınılması noktasında tenkit ettiği anlaşlan Haydarîzâde, huzurda bulunduğu bir sırada İstanbul'daki askerle Anadolu'daki askerin birleşmiş olduğunu ifade ederek eski sadrazamların padişah uğruna kendilerini feda ettiklerini, şimdiki padişahın ise sadrazam uğruna kendisini feda etmekte olduğunu söylemekten çekinmemiştir.

Ferid Paşa'nın ayrılması üzerine kurulan ve Kuvâ-yi Milliye ile uzlaşmaya önem vererek Ankara hükümetiyle irtibata geçecek olan Ali Rızâ Paşa kabinesinde meşihat makamını tekrar elde etmesi bu yoldaki siyasî davranışının bir sonucu olmalıdır. ${ }^{6}$

İstanbul'a Amerikalı bir gazeteci grubu gelmiş ve Şeyhülislâm İbrahim Efendi'ye bir takım sorular sormuşlardı. Meselâ; "Osmanlı Devletinin gerilemesine yalnız dini hususlardaki alakasızlık mı sebep oldu, yoksa bunun başka sebepleri de var mıdır?" Şeyhülislâm Hayderizade İbrahim Efendi şöyle cevap veriyor: “...Müslümanlar Selçuklulardan sonra Osmanlı bayrağı altında toplanmayı cana minnet saymiş ve dinin yükselmesi uğrunda ve hanedanin hizmetinde canlarını feda etmeyi en önde gelen bir vazife saymışlardı. Ne zaman ki Avrupa'da fen özel bir ilim halini kazanmakla beraber garb devletlerinin sanayi ve iktisadî gelişme ve galibiyetlerini takviye edecek derecede geldi. Bu terakki yolunu takib etmek dinin bir emri iken coğrafi yerinin kendisine temin ettiği vaziyete ve devletlerin rekabetine itimad ederek bu mühim işte gaflete düştügü için devletin geçmiş kudret ve azameti günden güne düşmeye başladı. Çünkü Kur'ân-ı Kerim'in her bir âyetinden anlaşılacağı üzere düşmanlığı umulan devletlerin tasallut ve galibiyetlerini daimi şekilde araştırmakla ona göre müdafaa ve mücadele vasitalarina koşmak ve dünyanin her tarafinda mevcut ütün ilim ve irfanı tetkik ve araştırıp çalışma yolunu takib ile âlemde mevcut ilim ve sanatlan ögrrenmek, ticaret ve ziraat işlerine sulûk eylemek gerekmekteydi. İste biz, dinin emretmiş olduğu bu ve benzeri bir çok ahlâkî, siyasi ve sosyal faziletlerden gafil oldu-

\footnotetext{
6 Mehmet İpşirli-Kemal Beydilli, "Haydarizade İbrahim Efendi", DİA, İstanbul 2000, 21/297-8.
} 
ğumuzdan istifade ile felaketimizi siyâsetlerinin bir meyvası sayan bazı devletler çeşitli sebepler icad ederek devletin iç işlerine müdahale ve müslüman olmayan unsurlar Osmanlı Devletinden uzaklaştırmaya muvaffak olarak vaziyetimizi bu hale getirdiler. Ve ne zaman devletle hakiki bir uslahat icrasına teşebbüs olundu ise açı ve gizli bir takım engellerin ihdası suretiyle kurtuluş ve terakkimize engel oldular."7

Ne yazık ki Hayderizâde İbrahim Efendi'nin bu görüşlerinin birkaç sene sonra samimi duygulardan ileriye geçemediği görülecektir. Sonra Türkiye'yi terke mecbur oldu. Tevfik Paşa'nın son istifasından sonra Haydarîzâde'nin Meclis-i Vükelâ'ya adaylığı bizzat Ahmed İzzet Paşa tarafından yapılmıştır. "Erdem ve kültürüyle gerçekten gözleri ve gönülleri dolduran Haydarîzâde'nin konuşmalar teselli verici idi" kayıtları, paşanın olumlu izlenimleri arasında yer almaktadır. Hilâfetin Osmanlı hânedanı elinde olmasının şer'an sıhhatinin her türlü şüphe ve tereddütten uzak olduğuna dair ortaya koyduğu kanaat ve bunun Osmanlı Devleti'nin dağılması sürecinin etkili bir silâhı olarak kullanılmaya çalışıldığı devrin güncel gelişmeleri esnasinda dile getirilmekte olması, buhranlı y1llarda mezhep tefrikalar1nın sakıncalarını vurgulaması ve özellikle Osmanlı hilâfetini bu anlamda takviye etme amacını gütmesi fikrî dünyasının mahiyetini göstermesi bakımından dikkat çekicidir. ${ }^{8}$ Arapça ve Farsça bilen Haydarîzâde'nin, dinî meselelerden ziyade siyasetle ilgilenilen son dönemin ağır gelişmeleri içinde şeyhülislâm olarak katıldığı hükümetlerde belirli bir kesimin kimliğini taşıyarak ağırlığını hissettirdiği, olup bitenlere "ümmü'l-havâdis" unvanıla anılacak kadar vâkıf olduğu anlaşılmaktadır. Amerika'daki içki yasağı dolayısıyla bu hususta İslâm dininin emirlerini anlamak için gelen Amerikalı bir ga-

\footnotetext{
7 Bkz.Ceride-i İlmiye, Y1l:5, Say1:51, Rebiülevvel,1338/1920, sh: 1622-3; Albayrak, Son Devir Osmanlı Ulemas, II, 172.

8 İpşirli-Beydilli, "Haydarizade İbrahim Efendi”, DİA, 21/297-8.
} 
zetecinin İbrâhim Efendi ile yaptığı mülâkatın tercümesi Cerîde-i İlmiyye'de neşredilmiştir. ${ }^{9}$

Hayderizâde İbrahim Efendi'nin adı içki ve sigarayla mücadele cemiyeti Yeşilay'ın kurucuları arasında geçmektedir. İstanbul'u işgal eden İngilizler, Müslümanların ahlakını bozmak, karakterini yok etmek için her çeşit ifsat komitesini faaliyete geçirmişlerdi. İşte bunlardan birisi Avrupa'dan büyük çapta beyin uyuşturan alkollü içkileri İstanbul'a getirmeleridir. Böylece Müslüman milletimizin havai, nefisperest olanlarını kendilerine çekmeyi planlıyorlardı. Buna karş1lı, onların idaresindeki İstanbul Hükümeti ise ahlak zabıtası gibi bazı tedbirleri içeren bazı kanunlar yaptı ise de etkili olmadı. Çünki hükûmetin o günlerdeki iradesi te'sirsizdi. Ç1karttığ kanunlar ve ahlâk zabıtası bunun önüne geçemiyordu. İşte tam o sıralarda ehl-i hamiyet ve ünlü din âlimlerinden müteşekkil bazı zatlar (Ord. Prof. Dr. Mazhar Osman Bey ve arkadaşları Şeyh'ül-İslâm Haydarizâde İbrahim Efendi'nin teşvik ve himayesi ile) Hilal-i Ahdar cemiyetini kurdular. Bilindiği gibi Yeşilay 5 Mart 1920 de yeşil hilal anlamına gelen Hilal-i Ahdar adıyla kurulmuştur. Bu cemiyetin üyeleri arasinda Şeyhülislam Haydarî Zade İbrahim, Dr. Tevfik Rüştü Aras, Eşref Edip ve Fahreddin Kerim Gökay gibi tanınmış simalar da bulunuyordu. ${ }^{10}$

\section{Eserleri}

Mezâhib ve Turuku İslâmiye Tarihi; Matbu bir eserdir. İstanbul'da Darü'l-Hilatefi'l-Aliye Evkafı İslâmiye matbaasında 1335 tarihinde basılmıştır. İslâm'da itikadî ve fikhî mezhepler, bunların orta-

9 Bkz. Ceride-i İlmiye, Y11: 5, Sayı: 51, Rebîülevvel 1338, s. 1619-1622; İpşirliBeydilli, "Haydarizade İbrahim Efendi", DİA, 21/297-8.

10 Bkz Fahreddin Kerim Gökay, "Yeşilay Nasıl Doğdu, Nasıl Gelişti?” Yeşilay, say1: 485, s. 7, Nisan 1974; Yeşilay, 1920'de İngiliz işgal güçlerinin İstanbul Limanı'na gemilerle getirdiği binlerce kasa alkollü içkiyi gençlerimize bedava dağıtıp onları zehirlemesine, işgale karşı direnişi kırarak özgürlüklerini ve onurlarını ellerinden almak istemelerine karşı alkollü içkilerle mücadele amaciyla dönemin Şeyhülislam'ı İbrahim Haydarizade'nin himayesinde Dr. Mazhar Osman Uzman ve arkadaşları tarafından Padişahın izniyle 1 Mart 1920'de İstanbul'da "Hilal-i Ahdar" adiyla kurulmuştur. http://www.yesilay.org.tr/tr/kurumsal/tarihce.html 
ya çıkış sebepleri, nübüvvet ve bid'at konularının ele alındığı eser, müellifin Medresetü'l-vâizîn'de bu isim altında okuttuğu ders notları mahiyetindedir. ${ }^{11}$ Vehhâbilik: Sebilürreşad Dergisi'nde dört ayr1 bölüm halinde yayımlanmıştır. Vehhabi mezhebinin kuruluşu, Muhammed b. Abdilvehhab'in hayatı ve fikirleri ele alınmış ve incelenmiştir. ${ }^{12}$

Emir bi'l-Ma'rûf Nehiy ani'l-Münker; Sebilürreşad Dergisi'nde yayınlanmış dört makaleden oluşmaktadır. ${ }^{13}$

Âlem-i İslâm'da Sa'y ve Amel yahud Teșebbüsü Șahsi; Sirat-1 Müstakim Dergisi'ndeki makale şeklinde yayımlanmıştır. ${ }^{14}$ Rüyâ (İstanbul 1329), Terkîb-i Bend (İstanbul 1330) ve Irak Ordusuna Hitab (İstanbul 1335) adlarını taşıyan küçük hacimli manzum eserleri basılmıştır. ${ }^{15}$ Şimdi de Sebilürreşad Dergisi'nde aynı başlıkla ayrı ayrı dört sayıda yayınlanan "Vehhâbilik" başlıklı makalelelere geçiyoruz.

\section{Vehhâbilik-1}

Vehhabi mezhebinin kurucusu bulunan Şeyh Muhammed (v.1206/1792)'in ortaya çıkmasıyla Vehhabi mezhebinin ne yolda tesise muvaffak olduğu hakkında Mezâhibi ve Turuku İslâmiye Ta-

11 Bkz. Ceride-i İlmiye, Y11: 5, Sayı: 51, Kasım 1919, sayfa: 1239; Bkz. Osman Ergin, Türkiye Maarif Tarihi, Eser Matb, İstanbul 1977, s. 164; DarülHilafeti'l-Aliye Medresesi Nizamname Ders Cetveli, s.14-15; Eser, Mezahib ve Turuku İslamiye Tarihi derslerinde Medresetü'l-Vaizin'de ders kitabı olarak okutulmuştur. Dr. Osman Oral tarafindan sadeleştirilip Yüksek Lisans Tezi olarak çalışılmıştır. Rekin Ertem tarafından sadeleştirilerek İslâm Mezhepleri ve Tarikatları Tarihi adıyla yayımlanmıştır (İstanbul 1981).

12 Bkz. Vehhabilik-1, Sebilürreşad, c.17, Sayı: 441, Ay:9, Y11: 1335, sayfa: 203205; Vehhabilik-2, Sebilürreşad, cilt: 17, Sayı: 442, Ay:9, Y11: 1335, sayfa: 216-218; Vehhabilik-3, Sebilürreşad, cilt: 17, Say1: 443, Ay: 10, Y11: 1335, sh. 3-5; Vehhabilik-4, cilt: 13, Say1: 443, Ay: 11, Y11: 1335, Sayfa: 64-66.

13 Bkz. Emir bi'l-Ma'rûf Nehiy ani'l-Münker-1, Sebilürreşad, Y1l: 1334, Ay: 9, cilt: 15, Say1: 368, Sayfa: 65-66; Emir bi'l-Ma'rûf Nehiy ani'l-Münker-2, Sebilürreşad, Y11: 1334, Ay: 9, cilt: 15, Say1: 370, Sayfa: 108-110; Emir bi'lMa'rûf Nehiy ani'1-Münker-3, Sebilürreşad, Y1l: 1334, Ay: 10, Cilt: 15, Say1: 372, Sayfa: 139-140; Emir bi'l-Ma'rûf Nehiy ani'l-Münker-4, Sebilürreşad, Y11: 1334, Ay: 10, Say1: 373, Cilt: 15, sayfa: 161-2.

14 Bkz. Siratı Müstakim, cilt: 6, Say1: 148, Ay: 6, Y11: 1327, Sayfa: 287-8.

15 İpşirli-Beydilli, "Haydarizade İbrahim Efendi", DİA, 21/297-8. 
rihi'nin müellifi âlisi fadıl muhterem Eski Şeyhülislam Hayderizâde İbrahim Efendi hazretleri tarafından kaleme alınan şu makaleler, Necd'de icrayı seyahatle bu konuda uzun uzadiya tedkikat ve araştırmada bulunmuş olan bazı âlimlerin gayrı matbu kıymetli eserlerinden iktibas edildiği cihetle büyük ehemmiyet ve kıymeti tarihiyeye haiz bulunduğundan muhterem okuyucularımız tarafından dikkatle takip buyrulmuştur.

Vehhabi mezhebi, Ehl-i Sünnet ve'l-Cemaat'in eski Hanbeli mezhebinin bir uzantısı olarak ortaya çıkmış bir mezheptir. Bu mezhep Sultan I.Abdulhamid zamanında ortaya çıktı. Kurucusu Muhammed b. Abdilvehhab (v.1206/1792) adlı kişidir. Abdilvehhab da Süleyman'ın oğludur. Süleyman Ali'nin, Ali Ahmed'in, Ahmed Raşid’in, Raşid Berid'in, Berid Muhammed'in, Muhammed Berid'in, Berid Müşerrefin, Müşerref Ömer'in, Ömer Bağdad'in, Bağdad Reysin'in, Reysin Zâhir'in, Zahir Muhammed'in, Muhammed Ali'nin, Ali de Vehbi Temimi'n-Necdi adlı kişinin oğludur. Bu mezhebin kurulması ve yayılmasinda hizmet eden yine Muhammed'dir. Abdilvehhab'in bu mezhebin inançlariyla katiyyen münasebeti yoktur. Mezhebin Abdilvehhab'a nisbeti mecâzidir. Hatta bu mezhebe âit bazı itikâdî meselelerden dolayı baba ile oğlu arasında çok büyük ihtilaf ve fikir ayrılığı vardır. Çünkü Abdilvehhab, oğlunun görüş ve fikirlerine cidden muhalifti.

Muhammed, Necd beldesinden ve Müseylemetü'l-Kezzab'in memleketi olan Yemame ${ }^{16}$ nahiyesinden olan Uyeyne kasabasında doğmuş ve babasının terbiyesi altında yetişmiştir. Babası o sıralarda

16 Yemame, Suudi Arabistan'da tarihi bir bölgedir. Arap yarımadasının ortasında bulunan Yemâme'nin yarımadayı oluşturan müstakil bölgelerinden birini ya da Hicaz, Necid veya Arûz bölgesinin bir parçasını teşkil ettiğine dair farklı görüşler ileri sürülmüştür. Genellikle Yemâme'nin Bahreyn bölgesiyle birlikte Arûz'u meydana getirdiği kabul edilir. Necd bölgesi Hz. Peygamber devrinde müslüman olmakla birlikte çok önceleri Yemen ve Aden, İran ve Hind, Irak ve Şam'ın tesiri altında çeşitli akidelere sahne olmuştu. Hz. Peygamberden sonra Müseylemetü'l-Kezzab, Secah, Tuleyha ve Esvedü'l-Ansi gibi yalancı peygamberler yine bu bölgede çıkmıștı. Sonraki dönemlerde muhtelif isyancı gruplar burada görülmüştü. Cahil, isyankar ruhlu, yağmacılığa mütemayil idiler. Bkz. Ethem Ruhi Fığlalı, Çağımızda İtikadi İslam Mezhepleri, İst, 1990, s.98; Mustafa L.Bilge, "Yemâme", DİA, 43/399. 
Uyeyne kadısı idi. Memuriyeti de meşhur Uyeyne emiri Muhammed b. Hamid b. Abdullah b. Muammer'in emirlik zamanına rastlar. Uyeyne o vakitte Muhammed'in elinden çıkmamış olduğu gibi Abdilvehhab da Hureymila Kasabasına henüz taşınmamıştı. Muhammed, Hanbeli fikhını babasından öğrenmekle beraber küçüklüğünden itibaren Tefsir, Hadis, Akaid gibi ilimleri tahsil etmiş ise de tahsil yolu bir âlimin görüş ve nezaretinde olduğundan dolayı âyet ve hadislerin zahirlerinden başka bir şeyi tanımamış ve bu durum ise kendisini dini görüsslerinde aşırı bir taassuba maruz kalmıştır. Bir kişinin dini konularda, kendi görüşüne dayanarak hüküm çıkarmaya kalkışması âlimlerin cumhurunun muhalefetiyle icma'ya kar\$̧1 gelmek gibi birçok tehlikeye maruz kalmasını gerektireceği tabiidir. İşte Muhammed böyle bir görüş sonucu idi ki birçok hususlarda Necd ahalisinin inançlarının hürriyetine taaruzla kendilerini tenkide cür'et eyledi.

Muhammed bu sıralarda Uyeyne'den ayrılıp Hicaz'a geçti. Hac'dan sonra Medine-i Münevvere'ye gelip aslen Necd'in Sedir Nahiyesindeki Mecmea beldesi reislerinden ve Seyfoğullarından "elAzbu'l-Faid fi ilmi Feraiz" isimli eserin müellifi Şeyh İbrahim’in pederi bulunan Abdullah b. İbrahim b. Yusuf'dan bazı ilimleri tahsil ve ta'im etti.

Muhammed, Medine-i Münevvere'de bulunduğunda halka $\mathrm{Hz}$. Peygamber'in kabrinde dua ve yardım istemelerinden dolayı kızar ve Cenab-1 Hakka karşı büyük vesile ve vasıta olan Rasululullah Efendimiz'in hâl ve hayatlarıyla ölümlerinin bir olduğu hakkında cumhuru ulemânın müttefik olduğu bu görüşü kabul etmezdi. Muhammed, Medine-i Münevvere'de bir müddet ikâmet ettikten sonra Necd'e döndü. Sonra Basra'ya geldi. Bir müddet Basra'da meşhur âlim Şeyh Muhammed Mecmui'nin ilim halkasına devam etti. Benimsemiş olduğu itikadi gereği herkesin benimsediği İslâm inançları aleyhinde bir takım tenkidlere başlaması üzerine Muhammed aleyhinde efkarı umumiye galebe gelerek kendisine türlü türlü cefa ve hakaretle Basra'dan sürgün ettikleri gibi Şeyh Muhammed'i kabul 
etmiş ve o vakte kadar herkesin hürmetine mazhar olan Şeyh Muhammed Mecmui ${ }^{17}$ hakkında da bir takım hakaretlere cür'et ettiler. Muhammed'in Basra'dan çıkarılması yaz mevsiminin şiddetli bir zamanına rastlamıștı. Basra ile Zübeyr kasabası arasını yürüyerek gitmiş, helak olmuştu. Zübeyr kasabası ahalisinden Ebu Hümeydan adında birisi onu bulup, yanındaki bineğe alıp, bu şekilde onu ölümden kurtarmıştı.

Ebu Humeydan, Muhammed’i Zübeyr kasabasina götürdükten sonra kasabada çok kalmayarak Şam'a gitmek üzere hareket ettiysede oraya gidemeyip Necd'e gelip Abdullah b. Muhammed b. Abdullatif eş-Şafii el-İhsai yanında bir zaman misafir kaldı. Oradan da yine Necd bölgesindeki Hureymila Kasabasina gitti.

Muhammed'in babas1 Abdilvehhab ise (1139) hicri senesinde Uyeyne Emiri Abdullah b. Muammer’in Taun hastalığı ile vefatı üzerine yerine geçen Muhammed b. Ahmed ile arası açılıp başka birisi yerine Kadı tayin edilmiş olduğundan dolayı Hureymila kasabasına dönmüştü. Muhammed bu münasebetle ikinci defa pederi nezdinde tahsil etmeye başladı. Fakat yukarıda da zikredildiği gibi baba ile oğul arasında bir çok itikadi konularda görüş ayrılığ ortaya çıkt1ğından dolayı aralarında gürültü ve münazara çıkmıştı. Hureymila ahalisi de bu yüzden Muhammed'in aleyhine döndüler.

Abdilvehhab'in 1153/1740 tarihinde vefatından sonra Muhammed, Ehli Sünnet inançlarına hakarete, reddetmeye halkı da kendi görüşlerini kabul etmeye davet etti. Hureymila ahalisinden baz1 kimseler Muhammed'in davetini kabul ettiler. Muhammed de şöhret bulmaya başladi. Hureymila beldesi o sirada bir kabileden yalılan iki firkadan ibaret idi. Memlekette her iki firkaya hâkim olabilecek bir kuvvet de yoktu. Bir kabile soygun ve öldürme gibi yasak hare-

17 Mecmua, Basra'da bir mahallenin ismidir. Bu mahalleye nisbetle Mecmui ismiyle tanınmisstır. Muhammed el-Mecmûrden dil bilimleri, hadis ve siyer tahsil etti. Çok karıșık dinî grupların bulunduğu bu şehirde Şîa ve çeşitli İslâm fırkaları hakkında bilgi edinme imkânı buldu. Özellikle halkta görülen velîlere ibadet derecesindeki hürmetin tezahürleri ve bunun sünnetle bağdasstırılmayan uygulamaları kendi tezini ileri sürmesine zemin hazırladı. Burada ortaya koyduğu fikirlerinden dolayı kendisi ve hocası şehirden uzaklaştirildi. 
ketleri yapabiliyordu. Muhammed de orada "emr-i bil maruf nehyi anil münker" prensibini ilan ederek bu fikri yayma faaliyetine girişti. Muhammed'in bu hareketi bazı grupları harekete geçirdi. Öldürmek üzere köleleri üzerine saldılar. İkamet ettiği evin etrafındaki komşular, şakilerin evin etrafını sardığını fark ederek bağırmaya başladılar ve bu suretle eşkiyalar kaçmıs, Muhammed'i katletmekten kurtarmişlardir.

Bu olaydan sonra Muhammed tekrar Hureymila'dan Uyeyne'ye gitmeye mecbur kald1. O sirada Uyeyne Emiri bulunan Osman b. Hamd b. Muammer, Muhammed'i iyi bir şekilde karşıladı. Hürmet ve ikramı yapmakla beraber her şekilde kendisine yardım etmeye söz verdi. Muhammed, Osman'in bu teahhüdüne cevaben; "Eğer kelime-i tevhid'in nusretinde yardım etmede bana sebat edersen Cenab-1 Hak da seni muvaffak edip Necd bölgesine malik olacaksın" dedi. Osman da Muhammed'in halkı davete başladı. Uyeyne ahalisinden bazı kimseler derhal Muhammed'e katıldılar. Muhammed o civarda Der'iyye ile Uyeyne arasında küçük bir köy olan el-Cebile de bulunan Ashab-1 Kiram'dan Zeyd b. El-Hattab (v.12/634)'in mezarın1, türbesini y1ktı.

Muhammed'in bu tarz hareketleri ve bu şekilde daveti halkı korku ve dehşete sevkeder. O sırada Emir bulunan Süleyman b. Ureyir ile ona tabi olan araplar ve ahaliye vasıl olması üzerine Süleyman tarafindan Osman b. Muhammed'e şiddetli bir mektup yazılıp Muhammed'in din işlerinde olan bu cüretinden dolayı katledilmesini emretti. Şayet bu konudaki emri uygulanmayacak olursa İhsa-Hasa imareti hazinesinden her sene Osmana verilmekte olan 1200 altının katiyetle verilmeyeceği de söylendi. Osman ise Süleyman'dan aldığ1 mektubu derhal Muhammmed'e gönderip bu husustan dolayı Süleyman ile savaşa gücü yetmeyeceğini bildirdi. Muhammed ise "her ne suretle olursa olsun bana yardimda bulunuran Necd ve civarina sahip olursun" diye tekrar Osman'dan yardım istedi. Fakat Osman cevabında "Süleyman sizin öldürülmenizi bize emretmiştir. Bizim de bu husustan dolayı harbe gücümüz yoktur. Sizin gibi bir zatın hayatına kasd etmek, öldürmek bize yakışmaz. Şu halde benim emrim 
dahilinde memleketlerimden çıkmanız zaruridir" dedi ve Muhammed'i çıkarmak için bir me'mur tayin etti.

Bundan dolayı Muhammed'in sevkine memur edilmiş olan atlı ile birlikte Uyeyne'den çıktılar. Muhammed yaya olarak görevli memurun ilerisinde gidiyordu. Ortalık mevsimin gereği olarak gayet sicak olmakla beraber Muhammed'in hakkında vaki olacak taarruz ve suikasda karş1 elinde bir sopadan ibaretti. Süvari, Muhammed'in bu şekilde kendisini müdafaa etmesini engellerken Muhammed'in öldürülmesini istediyse de o sırada zangır zangır titremeye başladı ve korkusundan derhal Muhammed'i tahliye edip Uyeyne'ye döndü. Memurun öldürme görevini yapmaması Osman'dan almış olduğu emre istinâden olduğu rivayet olmakta ise de bu rivayet birçokları tarafından yalanlanmaktadır. Bu olay hicri 1160 yılına rastlamaktadir.

Muhammed bu şekilde ölümden yakayı kurtardıktan sonra Der'iyye'ye yoluna devam edip Der'iyye'de Abdullah b. Süveylim Arabi'nin evine misafir oldu. Ancak Şeyh Muhammed Abdullah'in hanesinde de rahat edemeyip Der'iyye Emiri bulunan Muhammed b. Suud'dan dolayı hanesinin tekrar tehlikeye düşeceği düşüncesiyle oradan ayrild1. Bundan dolayı İbn Suud'a gidip halinden haber verip nasihat etmeye niyet etti. Ancak İbn Suud'un aile fertleriyle münasebet kurduktan sonra bu maksadın beyanını daha uygun buldu. Bundan dolayı Muhammed b. Suud'un kardeşi Süfyan ile bilhassa İbn Suud'un Kasiroğulları kabilesine mensup zeka ve akıllılığı ile meşhur bulunan zevcesi ve Ebi Vehhab'in kızı Muvazze ile görüştü. İbn Suud'a Muhammed hakkında bilgi veriliyordu. Muvazze kocası İbn Suud'a hitaben: "Bu kişinin size bugün gelip ihtiyacin arzetmesi her zaman olan ganimet ve nimetlerden değildir. Bir inayeti ilahi kabilinden olan şu tesadüften istifade etmeniz lazımdır" sözünü defalarca tekrar etti.

İbn Suud'un zevcesinin bu konudaki sözleri ve malumatları $\mathrm{Mu}-$ hammed'i güzel karşılamasını ve itikadını kabul etmesini kolaylaştırdı. Şeyh Muhammed'in misafir bulunduğu İbn Süveylim'in hanesine ziyaret etmekle beraber bir takim iltifat tabirlerle kati teminatlarda bulundu. Bunun üzerine Muhammed "her kim kelime-i Tevhi- 
de temessükle mucibince âmil olmak şerefine mazhar olursa bütün beldeler ve halk üzerine hâkim olacağından bütün Necd kıtasına kemali galibiyetle ve yakında hükümran olacağını" Şeyh Muhammed tarafından cevaben İbn Suud'u müjdeledi.

Bu sözlerden sonra Şeyh Muhammed Hz. Peygamber ile ashab-1 kiramın salik oldukları hidayet yollarını ve faziletli cihatlarını kısaca emir bi'l-maruf nehiy anil münker'den bilhassa Necd ahalisindeki bid'at ve zulümlerinden bahsetti. İbn Suud, dinin hakikatlarına tealluk eden bu ifadeleri Şeyh Muhammed'den dinlemesi üzerine galayane gelerek Şeyhe hitaben; -Sizin dini vazifenizi iyi bir şekilde yapabilmeniz için elimden gelebilecek her bir fedakârlığı yapacağım. Ancak bu hususta muvaffakiyet hâsıl olduktan sonra yanımızdan ayrilmak ve her sene Der'iyye ahalisinden almakta olduğum haracın alınmasına mani olmamak için şimdiden söz vermenizi isterim, dedi.

Şeyh Muhammed bu söze derhal İbn Suud'a doğru elini uzatarak "senin kanin benim kanim, senin kavgan benim kavgam" diyerek kendisinden ayrılmayacağına dair kesin suretle söz vermiş ve haraç hususundan dolay1 "Cenabr Hak sizi beldeleri fethetmek, ganimetleri çok almakla muvaffak etmek suretiyle size haraçtan daha büyük bir mükâfat vereceğimi ümit ederim" ibaresiyle idare-i kelamda bulunmuştur. ${ }^{18}$

\section{Vehhâbilik-2}

$\mathrm{Bu}$ olaydan sonra dini görevlerini yapmak ve cihat etmek üzere derhal Şeyh Muhammed Der'iyye'ye geldi. Şeyh, Der'iyye'yi bu suretle karargâh yaptıktan sonra reislerden vesaireden olup şeyhe mensup bulunan birçok kimselerle Osman b. Muammer'in adamlarından biri haydi zatlar da Der'iyye'ye hicret etmeye başladılar Diğer taraftan Osman İbn Muammer, İbn Suud'un Şeyhe yardım ettiğini, şan ve şöhretinin gün be gün yayılmakta olduğunu adamların bir çoğunun onun tarafına geçtiğini görünce hakkında yaptığı muameleden özellikle kendisini İhsa'dan çıkarmış olduğundan dolayı son

18 Haydarizâde İbrahim Efendi, "Vehhabilik-1", Sebilürreşâd, cilt: 17, sayı:441, Ay: 9, Y1l: 1335, sh: 203-205 
derece pişman oldu. Bunun üzerine Uyeyne'nin ileri gelenlerinden bazı kimselerle beraber şeyhin yanına geldi ve bir daha Uyeyne'ye geri gelmesi için 1srarda bulundu. Fakat Şeyh cevaben: -İbn Suud'un hakkımda göstermekte olduğu kemal, hürmet ve riâyete karşı kendisine şükranda bulunduğum için Uyeyne'ye dönüşüm onun görüşüne bağlıdır, müsaade ederlerse sizinle beraber gelirim, etmezlerse yanlarinda kalırm, dedi. Bunun üzerine Osman, İbn Suud'a müracaat etti. Fakat İbn Suud bu isteği reddetti. Osman da üzüntü ve pişmanlıkla geri döndü. Der'iyye halkı o sıralarda fakru zaruret içinde, geçimleri âciz bir durumda yaşamakta oldukları halde Şeyhin her gün meclisine devam edip vaz'u nasihatlerinden istifade ederlerdi. İbn Beşir Necdi diyor ki:

-Ben Der'iyye ahalisinin o zamanlardaki fakru zaruretlerini gördüğüm gibi bilahare İbn Suud'un zamanindaki hallerini de gördüm. İki zamana âit müşahedemdeki fark büyüktü. Kendilerini son derece fakru zarurette gördüğüm halde son seyahatimde son derece zengin ve muhteşem gördüm. Yani her türlü elbise ve zengin silahlarla donanmiş kuvvetlerle, fevkalade düzenli askerlerini gördüm. Hatta bir gün Batn ismiyle bilinen alışveriş yerine gittim. Erkek ve kadınlara ait Pazar yerleri başka başka idi. Altın, gümüs, silah, deve, koyun, zengin elise çeşitleri, buğday vs. eşyanın mevcudu lisanın anlatamayacağı derecede çoktu. Gözün alabildiği kadar büyük çarşıda satıcı ile müşterinin birbirlerine karşı söyledikleri "aldım-sattım” kelimelerinin hasıl ettiği sesler âdeta sahra, çöl hallerini tasvir ediyordu.

Şeyh Muhammed Der'iyye'yi vatan tuttu. Der'iyye halkı dini işlerde, farz ve vacipleri yerine getirmede gayet mükemmel ve iyi oldukları halde Şeyh Muhammed onları tamamıla kendi görüşlerine sevketmişti. Şeyhin esas daveti Tevhid ile Şirk'i terketmekten ibaretti. İlkönce -La ilahe illallah- kelimesinin manasını öğretti. "Bu kelime nefi ve isbattan ibarettir. Yani -La ilahe- terkibi bütün ilahları nefyettiği halde -ilallah- terkibi ibadetin yalnız Cenab-1 Hakka mahsus olup şeriki, ortağı olmadığına isbattır."

Gerek yıldızların gecenin, gündüzün, bulutların vs. nin vücudu gibi Vahdaniyet-i İlahiye ile Rububiyyetine delalet eden mahlukât1, Cenabı Hakk'a vermekle, emirlerine itaati, yasaklarından kaçınma- 
y1, İslâmın mebni olduğu rükünleri, farzları, tekrar dirilme (ba's), vs. inançları kendilerine öğretmeye ve izah etmeye başladı. Ancak daha önce de açıklandığı gibi Hz. Peygamber'e dua etmek vs. meselesinde aşırı gitti. Şeyh ahalinin dindeki cahilliklerini bu surette izale ettikten sonra şeyhin muhabbeti ahalinin kalbine esaslı bir şekilde yerleşti.

Şeyh Muhammed, Der'iyye'de nüfuzunu tamamiyla te'sis ettikten sonra Necd bölgesinin bütün beldelerini, kasabalarının reislerine hitaben kendisine itaatin lüzümü gerektiğine dâir davetnâmeler gönderdi. Kısmen itaat ettilerse de onların bir kısmı muhalefet ve isyan ettiler. Kimi sseyh hakkında hafife almaya, alay etmeye, kimi gizli muhalefete kalkıştılar. Şeyh ise emrine tabi olan Der'iyye ahalisini muhaliflerle derhal savaşmaya sevketti. Necd ve bilhassa İhsa ahalisiyle birçok defa vaki olan muharebesinde galebe temin etmeye muvaffak oldu. Necd ve İhsa-Hasa halkını itaat altına aldı. Suudogullarına mahsus olmak üzere gayet mükemmel bir Necd imaretinin teşkiline muvaffak oldu.

Din, mezhep, saltanat vs. gibi mühim esasların tesisi iddiasıyla meydana atılan birçok inkılaplarında görüldüğü üzere Şeyhde ifrat derecesinde cömertlik mevcuttu. Her muharebede çok elde ettiği ganimet mallarını bir veya iki şahsa hediye ederdi. Bu gibi mühim ınkılapların başarıya ulaşması için cömertlik ve malı dağıtma gibi vasıtalarla kapleri kazanması, onları etkisi altına alması ne derece mühim bir tesiri olduğunu izaha ihtiyaç yoktur.

Necid Emiri bile şeyhin emri olmaksızın hiçbir şeye el sürmezdi. Gerek emirin gerek maiyyetindeki emirler, askerle ve insanlar şeyhin emrinin dişına çıkmazlardı. Necid ahalisi ed Emir ile askerleri derecesinde şeyhe itaat ediyorlardı. Şeyh, âdeta dört imamdan biri derecesindeydi. Şeyhin ismini fena bir şekilde zikretmeye cüret eden bir kişi onların görüşlerinde öldürülmeye lâyık biriydi.

Riyad beldesinin de fethiyle Necid fetihleri son bulduktan ve Suudoğulları memleketi fevkalade genişleyip emniyet yerleri olduktan sonra Şeyh Muhammed, gerek ganimet mallarını, gerek sair emirlikleri Emir Abdulaziz'e birakıp ibadetle meşgul olmak üzere 
zaviye'ye çekildi. O da hicri 1206 tarihindeydi. Diğer insanlar gibi Şeyh Muhammed de 1206/1792 y1lında vefat etti.

Muhammed b. Abdilvehhab'in hayat hikayesi yukarıdaki sitarlardan ibarettir. Kurmuş olduğu mezhebin konuları arasında İslâm âleminde Muhammed'in aleyhinde tefrit ve dedikodulara sebebiyet vermiş olan görüşleriyle onun üzerine cereyan etmiş olan ilmi konulardan ve özellikle bu mezhebin kurulup yayılmasına bütün kuvvetiyle yardım etmiş olan İbn Suud'un nesebi ve âilesinin hususiyet ahvaline de ileride tabi ki açıklama yapmak zorundayı.

Evvelki makalemde de işaret olunduğu üzere Muhammed hadd1 zatında Necd kıtasında faziletiyle meşhur bir ilmi sülaleden olduğu gibi babası Abdilvehhab da Hanbeli mezhebi üzerine hükümleri icra ile memur Kadı sınıfından, hadis, fikıh ve diğer ilimlere de vâkıf âlimlerdendir. Birçok dini ve ilmi meseleleri Abdilvehhab'ın babası olan Şeyh Süleyman'da ilimde çok geniş yed-i tula (derinleşmiş, ihtisas) sahibi olup zamanında Necd fakihlerinden ve âlimlerinden say1lırd1. Vaktini kitap yazma ve ders verme ile geçirirdi. Âlimler arasinda bir yeri vardi.

Ne yazık ki Vehhabi mezhebinin müessisi bulunan Muhammed, ata ve ecdadının görüşleriyle iktifa etmeyerek dinde gayet müfrit bir taassub itikadı meydana getirmek, vaktin uleması aleyhinde şiddetli itirazlar ortaya atmakla kendisine inanmayanların küfür içinde olduklarına kadar gidip öldürülmelerine cevaz vermek, bu uğurda açtığ1 savaşlara Allah yolunda cihad ismini verip İbn Teymiyye (v.728/1328) ve İbn Kayyim (v. 751/1350) ve emsali gibi bazı kimseleri hariç tutarak Ravza-i Mutahhara'yı ziyareti ve Hz. Peygamber ile diğer enbiya ve evliyadan şefaatın cevazında ittifak ettikleri hususları şiddetle yasaklamak gibi görüşleri ortaya çıktı.

Şeyh Muhammed gerçi rivayete göre İctihad-1 Mutlak iddiasında idiyse de fetva ve ictihadının da tamamen İbn Teymiyye (v.728/1328)'ye dayandırıp ona muhalif olan görüşlere katiyyen itimad etmezdi. Bununla beraber İslâmın bir çok farzlarını, vaciplerini insanlara öğretme hususunda Şeyh Muhmmed'in sabıkalı olduğu da inkâr edilemez. Bazı insanlar istisnâ edilirse Şeyh Muhammed'in ortaya çıkmasından evvel Necd bölgesi âdeta dinin öğretil- 
mesinden mahrum bir bölgeydi. İslâm dininin bir çok hükümlerine Şeyhin himmetiyle öğrenebildiler. Ne üzücü bir durum ki dini konularda taassup ve aşırılığa gittiği için müslümanlar arasında bir çok bid'at ve büyük fitnelerin ortaya çıkmasına sebep oldu. Şeyh Muhammed'in bir çok tasnifleri ve te'lifleri vardır.

Kitabu't-Tevhid, Tefsiru'l-Kur'ân, Kitabu'ş-Şubuhat adlı eserleridir.

Şeyh Muhammed'in kendilerinden aldığı ilim, babası Abdulvehab ile Şeyh Muhammed b. Hayatis-Sindi'l-Medeni, Şeyh Abdullah b. Yusuf, Şeyh Muhammed el-Cemui vesaireden ibarettir. Rivayete göre Şeyh Muhammed vaktiyle Bağdat'a gelerek Irak sınırında allame ünvaniyla meşhur Hayderizâde Sibgatullan Efendi'den de ilim almıştır. Hatta Esad Efendi'den Der'iyye yoluyla Hicaz mağferi Tetraz'dan Bağdat'a dönüşünde Emir Necid Suud tarafından üç ay kadar bir zamandan fazla kendi nezdinde alıkoyması böyle bir münasebetden ortaya çıktğı da rivayet olunmaktadır.

Şeyh Muhammed'in Şeyh Hüseyin, Şeyh Abdullah, Şeyh Ali, Şeyh İbrahim isimlerinde dört çocuğu vard1. ${ }^{19}$ Şeyh Hüseyin babasının vefatından sonra makamına geçti ve Der'iyye'de kadılık vazifesini de yaptı. Şeyh Ali de Fıkıh ve Usülü, Tefsir ve Hadis âlimlerindendi. Bu da Beni Temim bölgesinde Kad1 olduğu gibi Faysal b. Türki'nin imaretinde Riyad Kadılığı'nda bulunmuştu. Şeyh Abdullah da vaktin âlimlerinden sayılırdı. Biraderi Şeyh Hüseyin'den sonra o da babasının makamına geçmiştir. Suud ile oğlu Abdullah'ın imaretleri zamanında o da Der'iyye kadısı olmuştur. Şeyh İbrahim

19 Muhammed b. Abdülvehhâb'dan sonra Vehhâbî fikriyatı bu dört oğlu, ayrıca torunları ve öğrencileri tarafından geliștirilmiștir. Kitâbü't-Tevĥ̂̀ üzerine yazılan şerhler XIX. yüzyıl Vehhâbî düşüncesinin en önemli ürünleridir. Torunlarından Süleyman b. Abdullah'in Teysîrü'l-Ǿazîz'i ile Abdurrahman b. Hasan'ın Fetĥu'l-mecîd'inden başka Hamed b. Atîk'in İbâlü't-tendîd'i bu bağlamda kayda değer eserlerdir. Bkz. Mehmet Ali Büyükkara, "Vehhabilik", DİA, 42/613 
de âlimlerden idiyse de babası ve kardeleri gibi Kadılık görevinde bulunmamıştır. ${ }^{20}$

\section{Vehhabilik-3}

Muhammed b. Abdilvehhab'in İctihadı Mutlak ${ }^{21}$ iddiasında olduğu ve bununla beraber görüşleri ve eserlerine göre Hanbeli Mezhebi büyüklerinden İbn Teymiyye (v.728/1328) ile ona tabi olan İbn Kayyim el-Cevziyye (v.751/1350)'nin görüşlerini taklid ederek itidalden saptığı etrafındaki bazı yanlış görüşlere kapıldığı evvelki makalelerde zikretmiştim. Halbuki ictihada lazım olan şartlardan ehemmiyet derecesine ve bu vasıflara hâiz kişilerin fikhına binâen ictihad kapısı dördüncü asırdan belki de üçüncü asrın sonundan itibaren kapalı olduğu bilinmektedir.

Hanefi âlimlerinden; Ebu Yusuf, Muhammed b. El-Hasan eşŞeybani, İbnü'1-Mübarek, Hasan b. Ziyad, Serahsi, Şemsü'1Eimmeti'l-Halvani, Seyyid Şerif Cürcani, Zemahşeri, Zahidi, Bakıllani, İbn Necim, Ayni, Nesefi, Hamevi, Dürrü'l-Muhtar ve Dürer sahipleri... Şafii âlimlerinden; Rebi', Buti, Muradi, İmamu'l-Haremeyn Cüneyd Bağdadi, Gazzali, Fahreddin Razi, Ebu İshak Şirazi, Subki, Beydavi, Askalani, Zerkeşi, Kastallani, Suyuti...Mâliki âlimlerinden; Halil Abdulvehhab, İbn Hacib, Behram, Zerkani, Muhyiddin Arabi, Ebu'l-Hasen Şazeli, İbn Haldun, İbn Battal, Buhari şarihi Berzeli, İbnül-Tayyib.... Hanbeli âlimlerinden; Hz. Abdulfadır Kilani, İbn Kudema, Münteha sahibi İbn Recep, Şehaeddin Askeri, Hatta kendilerinin taklid etmiş olduğu İbn Teymiyye ile İbn Kayyım elCevziyye ki yüzlerce kişi zuhur etmiş olduğu ve bunların hepsi bir çok kıymetli eser ve görüş meydana getirmiş oldukları halde hiçbiri-

20 Bkz. Hayderizâde İbrahim Efendi, "Vehhabilik-2", Sebilürreşad, Cilt:17, Say1:442, Ay:9, Y11: 1335, Sayfa: 216-218.

${ }^{21}$ Hükümleri bir mezhep gölgesi altında değil de kendi başına hüküm çıkarana ictihad-1 mutlak/kâmil müctehid denilir. Yani usul ve furu meselesinde başkasına tabi olmayan, kendi başına ictihad yapmasıdır. İbn Abdülhak elBağdâdî'nin tanımına göre ise mutlak müctehid, ictihad ehliyeti için gerekli olan bilgileri bir sıkıntıya düşmeden uygulamaya yansıtabilecek şekilde özümseyen ve herhangi bir meseleyi başka birine ihtiyaç duymadan tek başına çözebilen kişidir. Bkz. H.Yunus Apaydın, "İctihad", DİA, 21/439. 
si İctihad-1 Mutlak iddiasında bulunmamış, bunların hepsi dört mezhep imamina uymusstur.

İbn Teymiyye (v.728/1328)'nin görüşünün özeti şudur: Hz. Peygamber'in ve ashab-1 kiram'in görüşlerine uyulmalıdır. Cenab-1 Hakka ihlas ile ibadete münhasır bulunmakla Tevhid esasına muhalif olan her bir hareket, İslâmın yasaklarından sayılmıştır. Halkın dünyevi ve âhiret saadetini elde etmek maksadıyla Enbiya ve Evliya, hayırlı, mübarek kişilerin kabirlerine gidip onlarda bir kuvvet var olduğuna inanıp onlardan şefaat dilemek, kabirlere kurban kesmek, üzerlerine kubbe yapmak gibi şeyleri Ahmed b. Hanbel'in tecviz buyurmuş olduğundah bahs ile dinen yasak olduğunu açıklamış, Hz. Peygamber'in yüce maksadlarına vakıf olan Selef imamlarının, Enbiya ve salihinin kabirlerinde namaz kılmadıkları gibi onlardan istek ve yardımda da bulunmamışlardır. ${ }^{22}$

İbn Kayyim (v.751/1350) de bu konuda hocas1 İbn Teymiyye (v.728/1328)'ye tabi olarak İslâm beldelerinin her tarafında Evliya türbelerini ziyarette secde etme ve kurban kesmenin, kabirlerde yatanlardan şefaat ve yardım dileme gibi hususlarda gayet şiddetli bir lisan kullanarak şirkin bu gibi hallerden ortaya çıktığını beyan ederek diyor ki:

-Insanlar din ve hidayet yolunda iken kabirleri ziyareti ve oradaki süslere, resimlere hürmetin sonucu olarak hak yoldan dalalete sapmuşlardır. Ved, Siva, Yağut, Yaveg, Nesr isimlerindeki kişiler öldüklerinde resimleri yapılıp oturdukları mahalle yazıldiğı için onlara hürmet edilmeye başlanmiş, daha sonralar bu putlara ibadet edilmeye başlanmıştır. Daha sonralar Cenabı Hak, onlara imana davet için Nuh (a.s.)'ı gönderdi. Onlar da Hz. Nuh'a iman etmediklerinden helak oldular. Sonra Amr b. Amir bu putları deniz kenarindan alıp araplarin tapması için getirdi. Onlar da putlara inanmaya başladılar.

22 Vehhabilik, Hanbeli mezhebine bağlı olmakla beraber, Ahmed b. Hanbel'den sonra ikinci imam olarak İbn Teymiyye'yi tanırlar. Bkz. Ebu Zehra, İslam'da F1kh1 Mezhepler Tarihi, s. 532, 564, 566; Ferhat Koca, "İbn Teymiyye, Takiyyüddin", DİA, 20/394. 
İbn Kayyim bunlardan başka Semavi kitaplardan iktibasla muvahhidin için medar-1 ibret olan daha bir takım olay ve hadiseleri de anlatiyor.

Velhasıl gerek İbn Teymiyye gerek İbn Kayyyim kabirlere hürmet hakkında halkın ifratına karşılık onların ifrat derecesine çıkarak bütün kabirleri ziyareti yasaklamışlar. Türbelere kurban kesmek, kabirden yardım beklemek gibi fiilleri şirk cinsinden fiiller saymışladır. İşte Muhammed b. Abdilvehhab da bu noktadan hareket ederek İbn Teymiyye ve İbn Kayyim'in yasak saydıkları fillleri küfür hareketlerinden sayarak türblere kurban nezretmeyi veya dua etmeyi, etrafında tavaf etmeyi, elle dokunup öpmeyi, mübarek sayarak toprak almak, onlardan yardım istemek, onlara dua etmek gibi fiilleri yapanları kâfir diyor ve onları kâfir saymayanları da kâfir olmakla suçluyordu.

Hatta (Unvanu'l-Mecd fi Beyani Ahvali Bağdad, Basra ve Necd) isimli tarihin müellifi amcaoğlum Hayderizade İbrahim Fasih Efendi'nin Muhammed b. Abdülaziz b. Abdilvehhab el-Aidin-Necdi'den rivayet ettiğine göre Vehhabi mezhebinin müessisi Muhammed'e muasır olup Basra, Necd ve civarında ilim ve faziletle tanınmış Hanbeli mezhebinden âlim İbn Firuz el-İhsai isimli zata Muhammed b. Abdilvehhap tarafından hidayet yoluna daveti içeren mektupta Muhammed İbn Firuz'a:"De ki Ey Ehli Kitap. Sizinle bizim aramizda müşterek olan bir söze geliniz: Allah'tan başkasına tapmayalım. O'na hiçbir şeyi eş tutmayalım ve Allah'ı bırakıp da kimimiz kimimizi ilahlaştırmayasın..." (Âl-i imrân, 3/64) âyeti kerimesiyle hitap etmiş olduğundan dolayı İbn Firuz da ona cevaben: "De ki Ey Kafirler! Ben sizin tapmakta olduklariniza tapmam. Siz de benim taptığıma tapmıyorsunuz. Ben de sizin taptıklarınıza asla tapacak değilim. Evet, siz de benim taptığım Allah'a tapacak değilsiniz. Sizin dininiz size, benim dinim de banadır." (Kafirun, 109/1-6) âyetini yazmış. Bu olay üzerine İbn Firuz'u öldürmekle tehdit etmiş. Basra'ya kaçarak oraya yerleşmiş. Vefatına kadar orada kalmıştır. Bu sayede Şeyh Osman b. Sind, Şeyh Ahmed el-Camiu gibi birçok âlim İbn Firuz'un ders halkasına devam edip ilim ve feyz almışlardır. Gerek Muhammed'in ve 
gerekse Muhammed'in icra vasitası olan Suudoğulları Necd civarında bu inanç üzerine hareket etmişlerdir.

Kısaca Muhammed b. Abdilvehhab'ın vefatından sonra Necd imaretine geçmiş Suud'dan Faysal b. Türki tarafindan Necd ahalisine hitaben yazılmış olan tebli de o vakit İbn Kayyim'in zamanındaki müşrik araplardan kıyas ederek diyor ki:

-Bu zamanlarda insanların çoğundan öyle şeyler vaki olmaktadır ki o şeyler müşriklerden meydana gelmiş olan olaylarla aynıdır. Kur'ân-ı Azimüşşan'ı okuduklar halde bir mü'minin kalbinde öğle vaktindeki Güneşten daha açık ve aşikâr olan deliller ve hükümleri karşısında kendilerini kör ve sağır bir halde bulurlar. $O$, Tevhd-i Bari'de sahibi marifet olduğunu iddia eden kimse. Cenab-ı Hakk'ın kullarina ihsan etmiş olduğu bu nimeti oku ve O'ndan kudretini bil. Bu nimet Cenab-ı Hakk'in kullarina ihsan etmiş olduğu nimetlerden daha büyüktür. Bu nimete şükür ile karşıllk veriniz. Ondan habersiz olmakla küfürde bulunmayın. Şeytanin bu nimetden sizi men ve mahrum etmesinden kaçınınız. Bunu da biliniz ki ilim, zühd, vera, ibadet gibi özellikler ile mutasavvif olduklar halde bu tevhid görüşlerinde hataya düşmüş gruplar vardır. Bu gruplar ilimlerin semerelerinden ve güzelliklerinden mahrum kalmişlar, bundan evvel dalalete sapan bir takım kimseleri taklid ile birçok kimseleri doğru yoldan sapıtmışlardır. ${ }^{23}$

Vehhabî mezhebinin Necd civarında öyle az bir zaman içinde kuvvet kazanmasının sebeplerine gelince, Vehhabi mezhebinin ortaya çıktığı zamanda İslâm dininin ahlakı kavimler arasında kaybolmuş, şekavet, fisku fücür kabilelerde genişlemiş, dini emir ve hükümler bu civarlarda unutulmuş, arapların zalimleri de ortalıktaydı. İşte böyle bir zamanda idi ki Şeyh Muhammed, emri bi'l maruf nehyi ani'l-münker iddiasıla ortaya atılarak halkı adalet ve tev-

23 Faysal'ın bu gruplardan maksadı Muhammed b. Firuz el-İhsai ile bu gibi Necd âlimleri olduğu bilinmektedir. Halbuki bu hususta hataya düşen İbn Firuz değil, Faysal'dır. Çünkü İbn Firuz, ilim lezzetini tamamıla tatmış olan âlimlerden olduğu ittifak halindedir. Bir rivayete göre de Faysal'in şu yoldaki ta'n ve ta'rizi ile hedef gösterdiği grubun Ehl-i Sünnet ve'l-Cemaat'in cahil kalmış itikad sahibi avam tabakası ile gulat, aşırı şia'nın bazı gruplarıdır. 
hid yoluna davet ile zulüm ve dinsizliğin yayılma hissiyle gafil ve me'yus bir halde bulunmuş olan kabilelerin İslâmi hislerini uyandirdi.

Muhammed'in daveti ilahi bir davet telakki edildi. Bu mezhebin görüşlerinin ve hükümlerinin ilk zamanlarında kabileler arasında insanların katledilmesine, aşırılıklarına ve nice büyük fesatlıkların olmasina, İbn Teymiyye ve İbn Kayyim'ın görüşlerini ifrata varan şekilde taklid etmeleri, Şeyh Muhammed'in Tevhid esasanı aşırı görüşlere dayandırmasından kaynaklanmaktadır. ${ }^{24}$

Şia ehlinin aşırı, sapık kısmına mensup ve Necd bölgesinin İhsaHasa ve Katif kasabalarında oturan bazı Şia âlimlerinin inançlarıyla Ehl-i Sünnet ve'l-Cemaat'in bazı cahil kalmış olan avam tabakasının tavır ve dini görüşlerinintesir etmiş olması inkar edilemez. Çünkü Şeyh Muhammed, Şia'nın gulat, sapık kısmına menşub bulunan hulul'u kabul eden âlimlerin te'lif ettiği eserleri, Hz. Ali ve bazı zatların rızıklandığını, kendi zatlarına mahsus halleri olduğunu Ehl-i Sünnet'in bazı cahillerinin de evliyanın mezarlarının da Cenabı Hakk'a mahsus halleri olduğunu Ehli Sünnet'in inancinda bulunarak onlara ziyaretlerinde ruku ve secde vs. gibi Allah'tan başka hiçbir kimse için caiz olmayan bazı hareketlerden bulunduklarını görüyordu. Onların türbelerde ölülere değer verdiklerini, onlara ruku ve secde ettiklerini görüyordu.

24 Vehhabilik mezhebinin temelini Tevhid görüşü teşkil eder. Muhammed b. Abdilvehhab'a göre Tevhid, kalp, lisan ve amelle olmalıdır. Bunlardan birisi eksik olursa insan müslüman sayılmaz. Kanı ve malı helaldir. O'na göre Tevhid üçe ayrılır. Allah'ın isim ve sıfatlarında birlik, Rablıkta birlik ve Tevhidul-Uluhiyet yani Allah'tan basskasına duada, ricada bulunmamak, melek ve peygamber için bile kurban kesmememektir. Allah'tan başkasına dua eden, kurban kesen, nezreden kimse kafirdir. Malları ve canları helaldir. Hakiki muvahhidlerin bu müşriklere hucum ile bunları katl ve mallarını yağma etmeleri helaldir. Muhammed b. Abdülvehhâb, Kitâbü't-Tevĥî (Müellefâtü'ş-Şeyhi'l-İmâm Muhammed b. Abdilvehhâb içinde, nşr. Abdülazîz erRûmî v.dğr.), Riyad, ts; I, 28-67, 98-111, 138-139; Kitâbü Fażli'l-İslâm, I, 207-217; Keşfü'ş-şübühât, I, 171-177; Kitâbü'l-Cihâd, II, 359-360; Yusuf Ziya Yörükan, Vehhabilik, s. 65; Abdurrahman b. Hasan, Fethu'-Mecid, Kahire, 1957, s. 112 vd; Abdulkerim Polat, Teymiyyecilik, Vehhabilik, Fazilet Yay, İstanbul 1975, s.114 vd; Fığlalı, Çağımızda İtikadi İslam Mezhepleri, s. 106 vd; Osman Oral, İslam Mezhepleri Tarihi ve Terimleri, Ankara, 2014, s.98, 176 , 
Türbeler hakkında bu aşırı görüşleri ne Ehli Sünnet ve'lCemaat'ın ne de Gulat-1 Şia dışındaki Şia ehlinin görüşüdür. Onlar Evliya'nın şefaatinden başka bir itikatda bulunmazlar. Âlimlerin çoğu, cumhuru bu görüşte bir beis görmemiştir. ${ }^{25}$

\section{Vehhâbilik-4}

Bununla beraber gerek Muhammed gerek Muhammed'in icra makamında bulunan Suud Hanedân1, ister Ehl-i Sünnet ve'lCemaat'dan, ister sair İslâm firkalarından olsun kendilerine muhalif olanları nassların zahirine hamlederek küfür ile itham etmişler. İslâmın emrettiği bir çok meselede aşırı gitmişlerdir. Vehhabi mezhebini ta'n yönünü seçen o vaktin Necd âlimleri de ileri gittiler. Evet, İbn Teymiyye ve İbn Kayyım da Muhammed'in tekfir saydığı fiilleri şirk çeşidinden saymışlarsa da onların şirkten maksatları (şirk-i sağir) demek olup yoksa "Allah kendisine şirk koşulmasını asla bağışlamaz; bundan başkasını, dilediği kimse için bağışlar" (Nisa, 4/48;116) âyet-i kerimesinde zikredilen "şirk-i ekber" değildir. Çünkü Cenab-1 Hakk'ın bağışlamayacağı şirkin en büyüğü İslâm dininden çıkmak demektir ki putlar yahud ateş, su gibi şeylere ibadet ile mahluklardan birine hususi rububiyet verip Cenab-1 Hakk Teâlâ'ya şerik, ortak ve benzetme kabul etmekten ibarettir. Buna "Şirk-i Celi" de denir. "Şirk-i Hafi" ki Cenab-1 Hak'dan başkasina iltifat etmek demektir. Beşer nevi bir an bile bundan uzak olamaz. Rasuller ve büyük Enbiyalar hazretleri Şirk-i Celi'den müberra, uzak oldukları halde Şirk-i Hafi'den kurtulmak için Cenab-1 Hakk'a duâ etmişlerdir. İbrahim ve İsmail aleyhisselamların: "Ey

Rabbimiz! Bizi Sana boyun eğenlerden kıl! Neslimizden de sana itaat eden bir ümmet çıkar. Bize ibadet usullerimizi göster. Tevbelerimizi kabul et" (Bakara, 2/128) Ve Hz. Yusuf'un; "Beni müslüman olarak öldür ve beni salihler arasına kat" (Yusuf, 12/101) diye dua etmeleri bu manayı açıklamaktadır.

25 Hayderizade İbrahim Efendi, "Vehhabilik-3", Sebilürreşad, cilt:18, Sayı:443, Ay:10, Y1l:1335, sh:3-5. 
Elhasıl Şirk-i Hafi'nin çeşitleri olup "kötü duygularını kendisine tanrı edinen kimseyi gördün mü? Sen (Rasülüm) ona koruyucu olabilir misin?" (Furkan, 25/43) âyeti kerimesi gereğince nefs ve şehvetlere uymak bir nevi Şirk-i Hafi olduğu gibi riyâ da şirk-i hafidir, ameli iptal eder, derler. Ancak "riyâ yapanlar hep kâfirdir" diye "kanları ve malları helâldir" sözünü hiç kimse söyleyemez. Fakat İslâm âlimleri Güneş, Ay, Yıldız, Put gibi ilah kabul edilen şeylere kurban kesmenin küfür olduğuna açıklıyorlar. Allah'tan başkasına kurban kesmek, türbelere nezir, kurban adamak gibi fiilleri bazı âlimler haram saydıkları gibi türbelerde teberrüken toprak almaya etrafında tavaf gibi şeyleri de bazıları mekruhlardan saymışlardır.

Bu görüşün en fena noktası bu meseleyi Enbiyay-1 İzam hazretlerine kadar genişletmeleridir. Onları bu görüşe sevk eden "Ey Allahım! Sen benim kabrimi, tapinılan bir put haline getirme. Peygamberlerin kabirlerini mescide çevirenlere Allah'ın gazabı çok şiddetlidir" 26 hadis-i şerifidir. Halbuki hadis-i şerif, putlara secde edercesine Nebilerin kabirlerine secde ederek Allah Teâlâ'nın gadabına uğrayacakları merkezindedir.

İbn Teymiyye, "Selef imamları, Enbiya ve Salih kişilerin kabirleri/ mezarları yanlarında duâ ve istiğfarda bulunmazlardı" diyor. Bu ise sahih rivayetlerde reddedilmiştir. ${ }^{27}$ İbn Ebi Şeybe'nin rivayet ettiği üzere Hz. Peygamber'in her sene başında Uhud Gazve'sindeki şehitlerin kabirleri yanına gelip "Sabretmenize karşılık size selâm

${ }^{26}$ Bkz. İmam Malik, Muvatta, Kitabu's-Sefer 85; İbn Hanbel, Müsned, II/246.

27 Rasulullah (s.a.v.) kabristanı ziyaret etmiş, ashabına Kabristana vardıklarında şöyle demelerini öğretmiştir: "Selâm size ey gerçek dünyanın mü'min ve müslüman sakinleri. İnşaallah biz de yakında size katılacağı. Allah’tan size ve bize âfiyetler vermesini dilerim. Siz önümüzden gidenler, biz de arkanızdan gelecek olanlarız" (Müslim, Cenâiz 35; İbn Mâce, Cenâiz 36,103) "Selâm size ey mü'min kavimler yurdunun sakinleri. Yarın vaki olacak diye va'dolunageldiğiniz şey sizlere gelmiştir. Sizler, ölüm ile yeniden dirilme arasındaki müddette bekliyorsunuz. Biz de inşaallah size kavuşacağız. Ey Allahım! Bakiu'l-Garkad ahalisine mağfiret eyle. Herhangi bir kişi, sağlığında tanıyıp bildiği bir kişinin mezarının yanından geçer de ona selâm verirse, mezar sâhibi onu tanır ve sevinçle selâmını alıp iade eder..." (Müslim, Cenâiz 35) Bkz. Osman Oral, 100 Soruda âhiret Hayatı, İzmir, 2012, s.23 vd. 
olsun! Dünya yurdunu sonu (Cennet) ne güzeldir" (Ra'd, 13/24) âyet-i kerimesini okuyorlardı. Ehl-i Sünnet ve'l-Cemâat'in Şafii vs. mensup âlimleri kabir ziyaretlerinin caiz olduğu görüşündedirler. ${ }^{28}$ İmam Nevevi "ziyareti çok yapmak faziletli, Allah dostu kişilerin kabirlerini ziyaret ederek, dua edip durmak müstehaptır" diyor. İmam Subki (v.771/1370) de bu görüşünden dolayı İbn Teymiyye'nin hataya düştüğünü söylüyor.

Ümmetin hayırlılarının Allah'a yakınlığı sebebiyle Cenab-1 Hakk'a karşı şefkat vesilesi kabul olunmalarında dini bir mahur olmadığını isbat eden delillerden biri de Hz. Peygamber'in İmam Hz. Ömer'e hitaben "Ey Kardeşim" Dualarında bizi unutma"29 ibaresiyle vaki olan Hz. Peygamber'in iltifat beyanıdır. Bu, Allah nezdinde duânın kabulü için şefaatin yasak olmadığını beyan demektir. ${ }^{30}$ Yoksa Hz. Ömer'in bu konuda tevessülüne Hz. Peygamber'in ihtiyac1 yoktur.

$\mathrm{Bu}$ meselede âlimler arasında en fazla tartışılan konu mütekaddimin ve müteahhirin âlimler arasında birçok münakaşa olan "ziyaret için sadece üç mescide seyahat edilebilir. Mescid-i Haram, Mescid-i Rasulullah, Mescidi Aksa"31 hadisi şerifidir ki bu hadisi şerif hakkında kısac açıklama yapmak istedik. Âlimlerden bazıları bu konudaki hükmü genişleterek, ziyaretin maksadını kaybederek başka mescidlere yolculuğu şiddetle yasaklamış, bazıları da ifrad derecesine gidrek ziyareti yasaklayanı dalalette ve bid'atte olduğuna kadar götürmüşlerdir. Hadis-i şerifin maksadı bu üç mescid dışında

28 Önceleri Hz. Peygamber bu sebeple tehlikeli gördüğü kabir ziyaretini yasaklamıştı. Fakat tevhid inancı gönüllere iyice yerlessip Müslümanlar tarafından gayet iyi anlaşıldıktan sonra, kabir ziyaretine izin verilmiştir. Çünkü kabir ziyaretinde, hem hayattakiler, hem de ölüler için faydalar vardır. Hz. Peygamber Mekke seferi sırasında annesi Amine'nin kabrini ziyaret ederek ağlamış, etrafındakileri de ağlatmış ve Müslümanların kabirleri ziyaretine de izin verilmişti. Bkz. Müslim, Cenâiz, 36; Ebû Dâvud, Cenâiz, 77; Tirmizi, Salât, 21; Cenâiz, 60-61; Nesaî, Cenâiz, 104; İbn Mâce, Cenâiz, 49

29 İbni Mâce, menasik 5

30 Ehli Sünnet âlimlerinden Mâtürîdî, kabul ve reddedenlerin görüşlerini zikrederek yanlışlığını delilleriyle uzun uzun anlatır, Bkz. Mâtürîdî, Tevhid, s. 587-598; Te'vilâtü'1-Kur'ân, III, 362, IX, 168; Şefaat konusunda bkz. Yusuf Şevki Yavuz, "Şefaat", DİA, 38/413.

31 Buhari, Fezailu's-Salat 6; Hacc 26; Savm 67; Müslim, hacc 288; Tirmizi, Salat 243; Nesai, Mesacid 7. 
ziyaret için seyehat edilmesini yasaklamaktadır. Rihal, rıhle'nin çoğulu olup “devenin eğeri” demektir. Bu kelimenin sefer kelimesini ifade etmesi eğerin sefere lazım olmasından dolayıdır. Devenin sefer için zikredilmiş olması o zamanlarda sefer, Arabistan'da deve ile yapılmasından dolayıdır. Yoksa seferin at ve merkep ile yapilması arasinda fark yoktur.

Şeyh İbn Hacer Askalani'nin (Fethü'l-Bari An Sahihi'l-Buhari) adındaki kitabında beyan ettiklerine göre hadisteki (illa) harfiyle vaki olan istisna'ya göre bu üç mescitten başkasına yolculuk yapmak yasaktır. Bu mescidlerin diğer mescidlere göre faziletli olmalarının sebeplerinden birincisi bütün insanları toplaması, ikincisi eski ümmetlere kıble olmasından, üçüncüsünün de takva esası üzerine bina olunmasindan meydana gelmektedir.

Asıl ihtilaf, sağken veya ölmüş olan salih kişilerin tebrişleşmek vs. maksatlar için ziyaret edilip edilmeyeceği, oralarda namaz kılmak için seyahatin câiz olup olmadığıdır.

Şeyh Ebu Muhammed el-Cüveyni, hadisin zahirine göre "ziyaret için bu üç mescidin dişında yolculuk yapmak haramdır" diyor. Kadı Hüseyin bu görüşte olduğu gibi, Kadı Iyaz'da bu görüştedir. Sünen ashabının rivayet ettiği üere Ebu Hureyre'nin ziyaret için selehata çıkmasından dolayı Nusret Gufari tarafindan bu hadise istinâden hata ettiğini söylemiştir. Hatta Nusret Ebu Hureyre'ye "seyehata çıkmanızdan evvel size yetişmiş olsaydım çıkamayacaktın" demiştir. Yani hadisi bütün konulara şâmil hamletmiş, Ebu Hureyre de kendisine uymuştur, deniyor. İmamu'l-Haremeyn ile sair Şafii âlimleri şahıslar ve olaylar için seyehat etmek haram değildir. Bunlar da hadis-i şerifi te'vil ediyorlar.

Birincisi, ziyaretin altında seyehattan fazilet konusunun üç mescide âit olduğu,

İkincisi, yasak olan şeyin bu üç mescid dişındaki yerlere namaz kılmak kendi üzerine nezretmiş olan kimsye olduğudur. Böyle bir nezri, sözü yemini yerine getirmek maksadiyla bu üç mescid dışında bir mescide gitmenin câiz olmadığı. Bundan dolayı bir salihin veya bir garibin yahud ilim sahibini ziyaret yahud ilim tahsil etmek, tica- 
ret ve bir iş için seyehatin bu hükme dahil olamayacağı görüşünü söylüyorlar.

Bir rivayete göre Ahmed b. Hanbel, nehyin namaz için olduğu görüşündedir. Yani namaz için bu üç mescidden başkasına seyehat etmeyi câiz görmemiştir.

Bazı âlimlerce de hadis-i şerifin maksadı bu üç mescidin dışındaki mecidlerde itikafın olmayacağıdır. Bunlara göre bir kişi bu üç mescidden birisinde itikafa nezrederse böyle bir nezrin yapılması üzerine vacip olur. İmam Malik, Şafii ve Ahmed de bu görüştedirler. Yalnız Ebu Hanife mutlak vacip değildir, diyor.

Kirmani'nin rivayetine göre bu mesele hakkında vaktiyle Suriye'de bir çok münazara cereyan etmiş ve sonuçta Fahru Âlem Efendimiz'in kabirlerinin ziyaretini yasaklamış olanlar ilzam edilmiştir. İmam Mâlik hazretleri bir kişinin "Peygamerin kabrini ziyaret ettim" demesi mekruh saymışsa da bu konudaki görüşü ziyarete tealluk etmeyip Peygamberle ziyaretçi arasında manevi bir eşitliği sözkonusu yaptığını hissettirdiğinden edebsizlik kabul ettiğinden ötürüdür. Hz. Peygamber'in kabir ziyaretleri meşru, maddi ve manevi feyzler için şefaat vesilesi olduğu icma-i ümmet ile sabittir.

Hem de hadis-i şerifi başka bir teville de izah etmek mümkündür. Çünkü (üç mescid dişında) ibaresiyle o dişındaki mescidler mahzuf olduğu zikredilmediğine, bilinmediğine göre hadisin manası "herhangi bir işten dolayı olursa olsun üç mescidden başkasına hiçbir şekilde seyehat, yolculuk yapılmayacaktır" diyeceğiz veya hadis âlimlerinin araştırmalarıla Namaz ile te'vil edeceğiz. Birinci şeklin imkanı yoktur. Çünkü o halde ticaret, sıla-i rahim, ilim tahsil etmek için seyehat etmek câiz olmaması gerekir. Bu ise olmaz. O halde meseleyi ikinci görüşe göre hadis-i şerif'ten maksadın salat/namaz olduğu yönüdür. Bundan başka "kim beni ziyaret ederse şefaatim ona vacip olur" 32 , "Sizin kabir ziyareti yapmanız yasakla-

32 Beyhaki, Muhammed b. Hüseyn b. Ali, es-Sünenül-Kübrâ, Daru'l-Kütübi'lİlmiyye, Beyrut, 1994.V, 402. 
mıştım. Şimdi ziyaret edebilirsiniz"33 hadis-i şerifleri de bu konudaki hakikatlere açıklık getirir. Diğer makalelerde de beyan olunduğu üzere bazı cahil insanların evliya kabirlerini ziyaret ederlerken bir takım merasimle o mezar hakkında beslemekte oldukları itikad uygun değilse de bununla beraber bu kabilden olanların çoğunda Cenab-1 Hak'tan başka bir kimsede güç ve kudret olacağını inanmadıkları bilinmektedir. Şu halde bu yüzden bir müslümanın tekfir etmek tehlikeli bir meseledir.

Muhammed b. Abdilvehhab'n yasaklamış olduğu şeylerden biri de Evliya mezarları üzerlerinde yapılan yaldızlı ve süslenmiş kubbelerdir. Zaten bu gibi şeylerin insanların avam tabakalarının itikadları üzerinde kötü tesir bırakacağından dolayı İslâm âlimleri tarafindan mekruh sayılmıştır. Muhammed b. Abdulvehhab'in görüşüne göre tütün kullanılması da haramlardandır. Bu konudaki görüşü ise bu konuda haram diyen bazı âlimlerin eserlerinden alınmıştır. Gerçi bu konuda âlimler arasında bir ihtilafın varlı̆̆ biliniyorsa da birincisi tütünün haram olduğuna dâir açıkça bir nass yoktur. İkincisi, eşyada asıl olan mübahlık olması yönüyle haramlığı yönüne gidilemez. Çünkü haramlığa delil mevcut değildir. Haram olmas1 için delile ihtiyaç vardır. Kıyas tarafına da gidilemez. Çünkü dördüncü hicri asırdan veya üçüncü asır sonlarından itibaren ictihad özelliklerine hâiz âlim yetişmemiştir. Haram olduğu görüşünde olanlardan bazıları ise tütünde sarhoşluk hissi verdiğini iddia etseler de bu iddia da tütün içenlerce yalanlanmıştır. ${ }^{34}$

Sonuç olarak; Hayderizâde İbrahim Efendi'nin makalelerinden Vehhabiliğin ilk çıkışının siyasi olduğunu anlıyoruz. Vahhabiler Osmanlı Devletine karşı ayaklanmışlar, şiddetli savaşlara da girmişlerdir. İbn Teymiyye'nin kabir ziyaretleri ile ilgili görüşlerine taassub

33 İbn Mace, cenaiz 47

${ }^{4}$ Bkz. SSeyhülislam Hayderizade İbrahim Efendi, Vehhabilik-4, cilt: 13, Sayı: 443, Ay: 11, Y11: 1335, Sayfa: 64-66; Vehhabi mezhebi, sigaranin hakam olmasını aşağıda zikredilen sebeplerden dolayı değil "sonrada icad edildiği, bid'at olduğu" için haram kabul etmektedir. Yani haram kabul edilmesinin illeti, sebebi sünnet ve bid'at anlayışından dolayıdır. 
derecesine bağlı kalıp gizli bir kuvvet halinde varlıklarını korumuşlar, I. Dünya Savaşı'ndan sonra Arabistan, Osmanlıların elinden çıkınca Kral Abdülaziz b. Suud, Mekke ve Medine'ye hakim olan Haşimi âilesini mağlup etmiş ve Hicaz dahil Arabistan Yarımadası'nı ele geçirerek Suudi Arabistan Krallığını kurmuştur. Vehhabilik mezhebinin temelini Tevhid görüşü teşkil eder. Tevhid, ibadette Yüce Allah'ı bir kabul etmektir. Tevhid, Hz. Peygamberin bildirdiği her şeyden daha önemlidir. Namazdan, oruçtan, zekat ve hacdan daha muazzamdir. Tevhidi inkar eden kâfir olur. Tevhid, kalp, lisan ve amelle olmalıdır. Bunlardan birisi eksik olursa insan müslüman sayılmaz. Kanı ve malı helaldir. Şirk, bid'at, şefaat, vb. hepsi Tevhide dayanır. Allah'tan başkasına dua eden, kurban kesen, nezreden kimse kâfirdir şirke düşmüştür. Vehhabilere göre Meleklerden, Peygamberlerden, Velilerden vs. den şefaat dilemek/tevessül yani arac1 olmak müşriklerin özelliklerindendir. Kur'an ve Sünnette olmayan her şey bidattır. En korkutucu şirk bidatların başında mezarlar, türbeler ve ziyaretleridir. Osmanlılarda gördükleri türbeler için İslâmdışı kabul ettiklerinden hep yıkmışlardır. Hz. Hatice, Hz. Peygamber, Hz. Ebubekirin evinin kubbeleri, türbeleri ve süslerini yıkmışlardır. Hırka-i Şerif, Sakalı şerif şirktir, bidattır. Peygambere Seyyiduna, Mevlana dememek gerekir. Mevlit okutulması, camilerin süslenme, kubbe ve minare yapılması, bidattır. Namazların cemaatle kılınması gerekir. Müteşabih âyetler te'vil edilmeksizin zahirlerine göre hükmolunur. Bunları te'vil etmek küfürdür. İbn Teymiyye'nin görüşlerine Vehhabilerin sıkı sıkıya bağlanmaları ve bunları âlimleri vasıtasıyla yaymaya çalışmaları, kendilerine has bir kültür doğurmuş, ümmi oldukları halde Arabistan Yarımadası'nın büyük bir kısmını ele geçirince bu kültürü, yarımadanın her tarafına yaymaya çalışmışlardır. Vehhabilik Hanbeli mezhebine bağlı olmakla beraber, Ahmed b. Hanbel'den sonra ikinci imam olarak İbn Teymiyye'yi tanırlar. Ezcümle Şeyhülislâm Hayderizâde İbrahim Efendi'nin araştırmasından anlaşılan Vehhabilik Ehli Sünnet ve'l-Cemaat dairesindedir. Selefi çizgide Hanbeli mezhebi uzantısındadır. 


\section{BİBLIYYOGRAFYA}

Abdurrahman b. Hasan, Fethu'l-Mecid, Kahire 1957

Albayrak, Sadık, Son Devir Osmanlı Ulemâsı, Medrese Yay, İstanbul 1980

Altınsu, Abdulkadir, Osmanlı Şeyhülislâmları, Ayyıldız Matbaası, Ankara 1972

Apaydın, H.Yunus, "İctihad", Diyanet İslam Ansiklopedisi, cilt: 21, İstanbul 2000

Beyhaki, Muhammed b. Hüseyn b. Ali, es-Sünenül-Kübrâ, Daru'lKütübi'l-İlmiyye, Beyrut, 1994.

Bilge, Mustafa L, "Yemâme", Diyanet İslâm Ansiklopedisi, cilt: 43, İstanbul 2013

Büyükkara, Mehmet Ali, "Vehhabilik", Diyanet İslâm Ansiklopedisi, cilt: 42, İstanbul 2012

Ceride-i İlmiye, Yı1: 5, Sayı: 51, Kasım 1919, sayfa: 1239.

Danişmend, İsmail Hami, Osmanlı Devlet Erkânı, Türkiye Yay, İstanbul 1971

Darül-Hilafeti'l-Aliye Medresesi Nizamname Ders Cetveli, s.14-15.

Ergin, Osman, Türkiye Maarif Tarihi, Eser Matb, İstanbul 1977

Fığlalı, Ethem Ruhi, Çağımızda İtikadi İslâm Mezhepleri, İstanbul, 1990

Gökay, Fahreddin Kerim, "Yeşilay Nasıl Doğdu, Nasıl Gelişti?” Yeşilay, say1: 485, s.7, Nisan 1974

Haydarizâde İbrahim Efendi, Şeyhülislam, Sebilürreşâd, cilt:17, say1:441, Ay:9, Y11:1335

-------, Sebilürreşad, Cilt: 17, Sayı: 442, Ay: 9, Y11: 1335

-------, Sebilürreşad, cilt: 18, Sayı: 443, Ay: 10, Y11: 1335

--------, Emir bil maruf nehiy anil münker-1, Sebilürreşad, Yı1:1334, Ay: 9, cilt:15, Say1:368

--------, Emir bil maruf nehiy anil Münker-2, Sebilürreşad, Y11: 1334, Ay: 9, cilt: 15, Sayı:370

-------, Siratı Müstakim, cilt: 6, Sayı: 148, Ay: 6, Y11: 1327 
--------, Emir bil maruf nehiy anil Münker-3, Sebilürreşad, Y11:1334, Ay:10, Cilt:15, Sayı:372

--------, Emir bil ma-ruf nehiy anil Münker-4, Sebilürreşad, Y11:1334, Ay:10, Say1: 373, Cilt: 15

--------, Vehhabilik-1, Sebilürreşad, c.17, Sayı: 441, Ay:9, Y11: 1335

-------, Vehhabilik-2, Sebilürreşad, cilt: 17, Sayı: 442, Ay:9, Yı1: 1335

-------, Vehhabilik-3, Sebilürreşad, cilt: 17, Say1: 443, Ay: 10, Y11: 1335

-------, Vehhabilik-4, cilt: 13, Say1: 443, Ay: 11, Y11: 1335

http://www.yesilay.org.tr/tr/kurumsal/tarihce.html

İbnül-Emin Mahmut Kemal İnal, Son Sadrazamlar, İstanbul 1969

İpşirli, Mehmet-Kemal Beydilli, "Haydarizade İbrahim Efendi", Diyanet İslâm Ansiklopedisi, cilt: 21, İstanbul 2000

Muhammed b. Abdülvehhâb, Kitâbü't-Tevhîd (Müellefâtü'ş-Şeyhi'lİmâm Muhammed b. Abdilvehhâb içinde, nşr. Abdülazîz er-Rûmî v.dğr.), Riyad, ts

Oral, Osman, 100 Soruda Âhiret Hayat1, İzmir 2012

-------, İslâm Mezhepleri Tarihi ve Terimleri, Tiydem Yay, Ankara 2014

Öztuna, Yılmaz, Devletler ve Hanedanlar, Kültür Bakanlığı Yay, Ankara 1989

Polat, Abdulkerim, Teymiyyecilik, Vehhabilik, Fazilet Yay, İstanbul 1975

Türk Ansiklopedisi, MEB cilt: 19, Ankara 1971

Yavuz, Yusuf Şevki, "Şefaat", Diyanet İslâm Ansiklopedisi, cilt: 38, İstanbul 2010

Yörükan, Yusuf Ziya, "Vahhabilik", A.Ü. İlahiyat Fakültesi Dergisi 1953 